\title{
A Case of Desmoid-Type Fibromatosis Occurring Around the Transverse Process of Cervical Vertebra
}

\author{
Chae Dong Yim ${ }^{1}$, Jin-Pyeong Kim ${ }^{1}$, and Seung Hoon Woo ${ }^{1,2}$ \\ ${ }^{1}$ Department of Otorhinolaryngology, ${ }^{2}$ Institute of Health Sciences, Gyeongsang National University School of Medicine, Jinju, Korea
}

\author{
경추 가로돌기 인접한 곳에서 발생한 유섬유형 섬유종증 1 예 \\ 임채동 ${ }^{1} \cdot$ 김진평 ${ }^{1} \cdot$ 우승훈 $^{1,2}$ \\ 경상대학교 의과대학 이비인후과학교실, ${ }^{1}$ 건강과학원 ${ }^{2}$
}

\author{
Received September 13, 2016 \\ Revised November 9, 2016 \\ Accepted November 10, 2016 \\ Address for correspondence \\ Seung Hoon Woo, MD \\ Department of Otorhinolaryngology, \\ Gyeongsang National University \\ School of Medicine, \\ 79 Gangnam-ro, Jinju 52727, Korea \\ Tel $+82-55-750-8173$ \\ Fax $+82-55-759-0613$ \\ E-mail lesaby@hanmail.net
}

Fibromatosis is generally a benign tumor that arises from the musculoaponeurotic tissues of the body, rarely occurring in the head and neck region. This can be treated with a good prognosis, but sometimes recurs as a local invasion. Preoperative core needle biopsy and MR images are necessary to diagnose preoperatively and outline the tumor extent. The mainstay of treatment is complete surgical excision. Nonetheless, an excision is often difficult because of the complex anatomy or proximity of the tumor to vital structures in the head and neck region. We report a rare case of desmoid-type fibromatosis that occurred in the neck, closely attached to the transverse process of the cervical vertebra. The present article covers an extensive analysis of the case with a review of the related literature.

Korean J Otorhinolaryngol-Head Neck Surg 2018;61(3):156-9

Key Words Aggressive fibromatosis - Cervical vertebrae.

\section{서 론}

섬유종증(fibromatosis)은 발생부위에 따라 크게 복강에서 발생하는 것(abdominal fibromatosis)과 복강 외에서 발생하는 것(extra-abdominal fibromatosis)으로 나눌 수 있다. ${ }^{1)}$ 이 질환 은 두경부 영역에서 드문 양성 종양으로 근건막계의 섬유아세 포가 증식하여 발생하며, 조직학적으로 양성이지만 주위 조직 을 잘 침범하며 절제 후 국소 재발을 잘하는 경향이 있다.,2)

섬유종증은 임상적으로는 성인에서 경계가 좋지 않은 단단 한 종괴의 형태로 나타나고, 대부분 어느 정도 크기로 성장할 때까지 무증상이며 발견 당시 크기가 커져 이로 인한 압박 증 상이 가장 흔하다. 치료로는 종양의 완전한 절제가 필요하다. 두경부에 발생한 섬유종증의 경우 인접한 부위에 경동맥, 기

This is an Open Access article distributed under the terms of the Creative Commons Attribution Non-Commercial License (http://creativecommons.org/licenses/by-nc/4.0) which permits unrestricted non-commercial use, distribution, and reproduction in any medium, provided the original work is properly cited.
관, 식도, 뇌신경 등 중요한 구조물이 많고 근막면이 복잡하 여 완전 절제가 어려운 경우가 많으며, 종양의 절제 범위까지 침범되어 있는 경우에는 재발률이 높은 것으로 알려져 있다.,3)

두경부 영역에 발생한 섬유종증은 국내 문헌에 드물게 보고 되어 있으며, 흔히 접하는 질환은 아니어서 이전에는 술 후 조 직검사를 통해 진단되는 경우가 많았으나 최근에는 중심부 바 늘 생검(core needle biopsy)으로 진단되는 사례가 늘고 있다.

저자들은 6개월 전에 우연히 발견한 우측 경부의 종물이 크기가 증가하여 내원한 남성이 영상검사와 중심부 바늘 생 검을 시행하여 술 전에 섬유종증을 진단받고 수술적 치료 후 방사선 치료를 시행한 증례를 경험하여 문헌고찰과 함께 보고 하고자 한다.

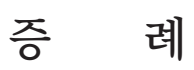

36세 남자 환자가 6개월 전에 우연히 우측 경부 종물을 발 
견하고 동반 증상 없이 지내다 종물이 점점 커져서 외부 병원 방문 후 본원 이비인후과로 전원되었다. 우측 경부의 종물은 $7 \mathrm{~cm}$ 정도의 크기로 단단하였고 약간의 가동성은 있었다. 우 측 어깨 통증은 없었으며, 신체 검사에서 종물 촉진 시 압통 을 비롯한 다른 이상 소견은 없었다. 또한 어깨 부위 외상 및 수술 등의 과거력은 없었다.

내원 전 외부 병원에서 시행한 경부 초음파검사에서 우측 등세모근과 어깨올림근 사이의 빗장위 오목에 위치한 불균 질한 에코음영이 섞여 있는 난형의 연부조직 종양이 의심되어 초음파 유도하에 중심부 바늘 생검을 시행하였으며, 조직검 사결과 섬유종증으로 진단되어 본원으로 수술적인 치료를 위 해 전원되었다.

외부 병원에서 시행한 경부 전산화단층촬영에서 우측 빗장 위 오목에 위치한 어깨올림근 부위에서 장경 $7.28 \times 3.72 \mathrm{~cm}$ 크기의 저음영의 난형 종물이 관찰되었다(Fig. 1). 보다 정확
한 검사 및 수술전 평가를 위해 자기공명영상을 촬영하였다. $\mathrm{T} 1$ 강조영상에서 저신호 강도를, $\mathrm{T} 2$ 강조영상에서 고신호 강 도를 보이며 조영 증강되는 침윤성 연조직 종물이 우측 어깨 올림근 부위에서 관찰되었다. 또한 종물과 띠처럼 연결된 조 직이 우측 4번 경추뼈의 가로돌기에 이어져 있는 소견이 관 찰되었다(Fig. 2).

기능면에서 장애는 없었지만 종물이 지속적으로 커지고 있 어 수술을 시행하였다. 병변 부위에서 횡절개를 가한 후 피판 을 거상하였다. 빗장위신경을 보존하면서 종물 상방의 연부조 직을 제거하여 병변을 노출하였다(Fig. $3 \mathrm{~A}$ ). 종물은 우측 어 깨올림근을 중심으로 우측 경추 가로돌기와 강하게 유착되어 있었고 상완신경총의 침범은 없었다. 침범된 근육의 일부를 포함하여 종물을 절제한 후 연접한 경추뼈 가로돌기의 일부 를 제거하여 최대한 남는 조직이 없도록 하였다(Fig. 3B). 육안 소견으로 검체는 $7.5 \times 6 \times 4 \mathrm{~cm}$ 크기의 일부는 피막으로 둘러
Fig. 1. The neck CT shows a $7.28 \times$ $3.72 \mathrm{~cm}$ sized, homogenous low density soft tissue mass at the right supraclavicular area (arrow) (A: coronal view, B: axial view).
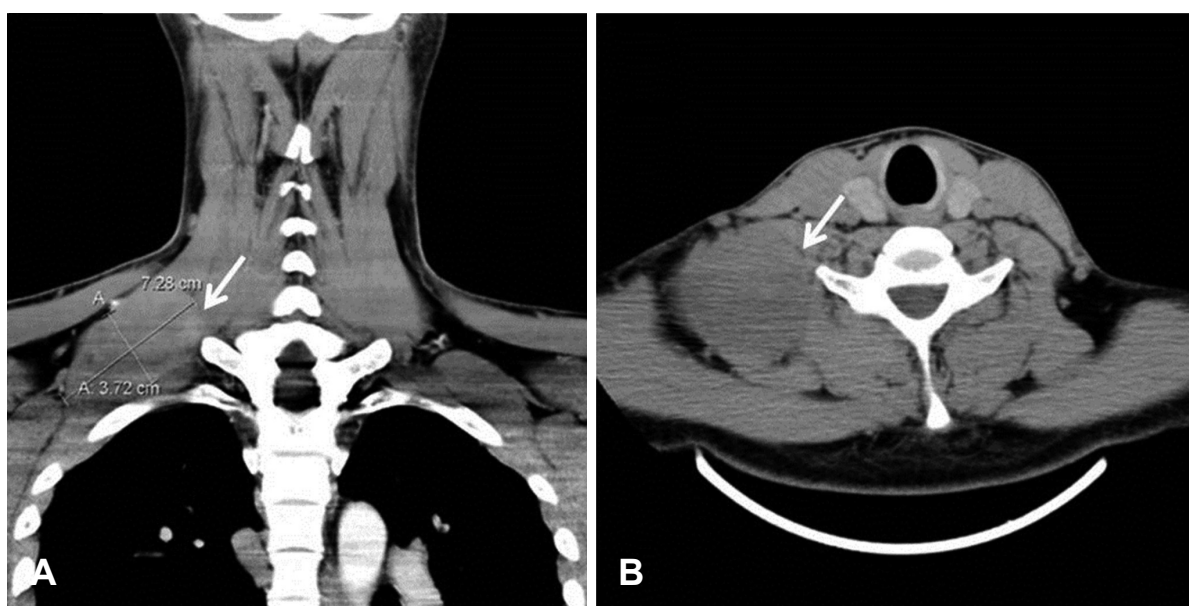
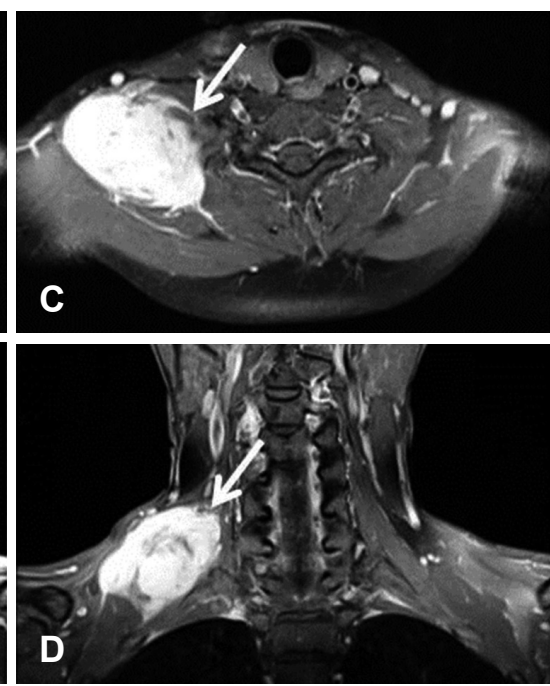
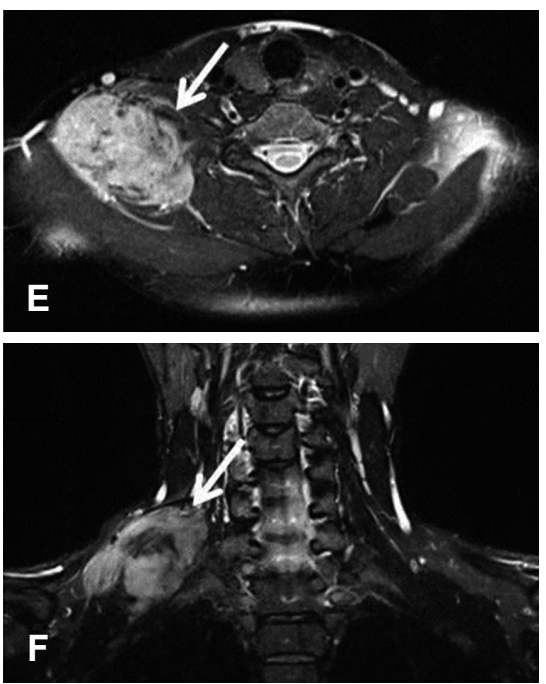

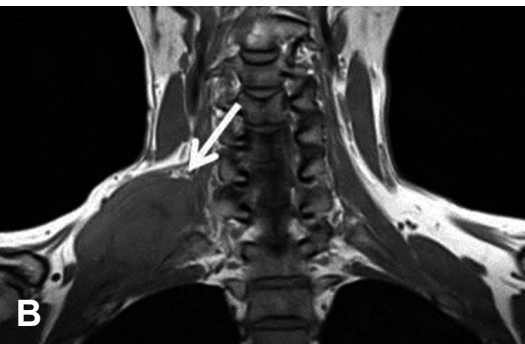

Fig. 2. Preoperative axial and coronal MR images. Infiltrative soft tissue mass (arrow) in the supraclavicular area shows low signal intensity in T1 weighted images (A and B), contrast enhancement in T1 weighted images obtained after intravenous injection of gadolinium ( $C$ and $D$ ), and heterogenous high signal intensity in T2 weighted images ( $E$ and $F$ ). 

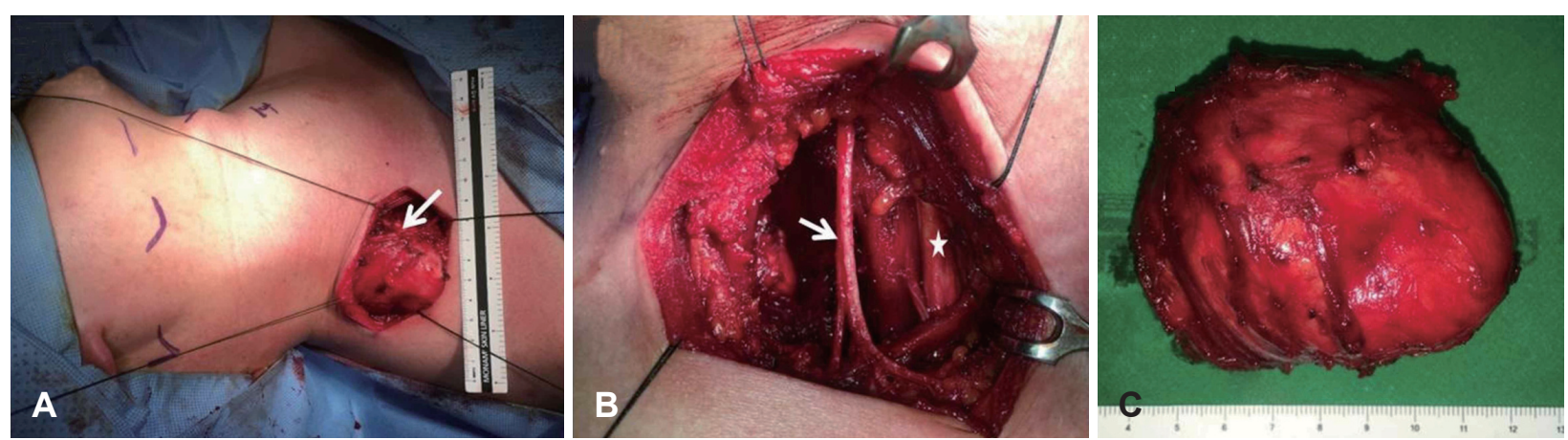

Fig. 3. Intraoperative photographs. After the fat tissue is removed in supraclavicular area, total tumor resection is performed to save the supraclavicular nerve (arrow) (A). After mass removal, the supraclavicular nerve (arrow) and brachial plexus (asterix) remain intact (B). About $7.5 \times 6 \times 4 \mathrm{~cm}$ mass is excised $(C)$. The mass is attached strongly to the transverse process of cervical vertebra and contained tense fibers.

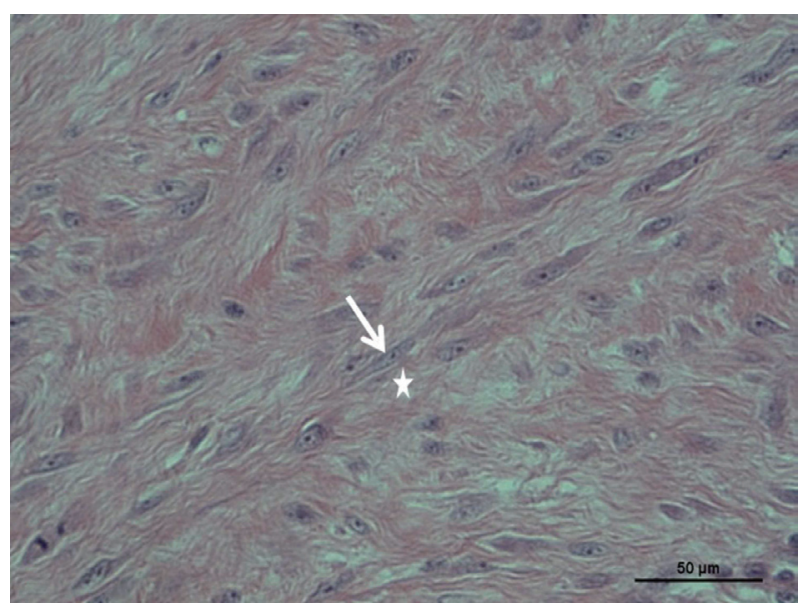

Fig. 4. This pathologic picture shows the desmoid-type fibromatosis consisting of spindle cell of fibroblasts (arrow) and collagen bundles (asterix) (hematoxilin \& eosin stain, $\times 400$ ).

싸인 백색 종물로 주위 근육을 침윤하고 있었다(Fig. 3C). 결 손부위는 배액관 1개를 넣고 압박 소독을 하였다. 조직병리 소견은 방추형 세포들로 구성된 섬유다발 사이에 교원섬유속 (collagen bundle)이 관찰되어 유섬유형 섬유종증(desmoidtype fibromatosis)으로 진단되었다(Fig. 4).

술 후 우측 어깨의 불편감은 호소하였지만 어깨 운동을 비 롯한 다른 이상 소견은 없었으며, 술 후 5일째에 퇴원하였다. 주요 구조물과 인접해 있어 충분한 절제연을 확보하지 못하여 재발을 예방하기 위해 추가 방사선 치료를 권유하여 수술 부 위를 포함하여 빗장위 부위에 총 $5000 \mathrm{cGy}$ 계획하에 시행하 고, 현재 외래 경과관찰 중이다.

\section{고 찰}

섬유종증은 발생위치에 따라 복강 내 및 복강 외 섬유종증 으로 나뉘며, 특히 임상적으로 국소 재발을 잘하는 특성이 있 는 공격성 섬유종증(aggressive fibromatosis)의 경우 병리학
적으로는 유섬유형 섬유종증(desmoid-type fibromatosis)으 로, 육안적으로는 건(tendon)과 같은 모양을 하고 있어 유섬 유종(desmoid tumor)으로 불리기도 한다.) 섬유종증은 근건 막계(musculoaponeurotic system)에서 기원하는 양성 섬유성 증식 병변으로, ${ }^{2)}$ 인구 백만 명당 2.4 4.3명의 발생빈도를 보 이는 매우 드문 질환이며, 모든 섬유종증의 $2 / 3$ 가 복부에서 발생한다. ${ }^{5)}$ 복강 외 섬유종증 중 두경부에서 발생하는 섬유 종증은 약 10 25\% 정도를 차지하고, 경부, 얼굴, 구강 내, 두 피 등에 발생하는 것으로 알려져 있다. ${ }^{1-3,5-7)}$

섬유종증의 발병요인에 대해서는 여러 가설이 있다. 섬유종 증 환자에서 수술 등 외상의 병력이 있는 경우가 많아 수술 부 위의 미성숙 섬유아세포가 증식하면서 종양을 형성한다는 가 설도 있고, 임신 혹은 에스트로겐이 높은 경우에 섬유종증의 증식이 가속되는 경향이 있어 호르몬에 의한 발생한다는 가설 도 있다. 또한 가드너 증후군(Gardner syndrome)과 같은 유전 질환에서 섬유종증의 유병률이 높은 것으로 보고되고 있어 유전인자에 의해 발생한다는 가설도 있다. ${ }^{1,24}$

섬유종증의 진단은 절제 후 조직검사를 통해서 가능하다. 종양은 경계가 잘 지워지지 않는 회백색의 결절로서, 병리학적 으로 다양한 분화를 보이는 섬유모세포들로 구성된다. 섬유 종증은 세포 밀도가 낮고 교원질이 풍부하며, 방추형 세포들 로 구성된 섬유다발 사이에 교원섬유속(collagen bundle)이 관찰되는 병리학적 소견을 보인다. ${ }^{4)}$ 병리학적으로 세포 밀도가 높은 경우는 섬유육종(fibrosarcoma)과 감별하여야 하며, 낮 은 증식능과 아교질의 침착 그리고 세포의 이형성이나 이상 유 사분열이 없다는 점으로 감별할 수 있다. ${ }^{4)}$ 섬유종증은 병리학 적으로 분류하였을 때 유섬유형 외에도 다세포형(cellular type) 과 섬유아세포형(fibroblastic type)으로 나누기도 한다. ${ }^{8)}$

세침흡인검사로는 진단하기에 충분한 조직을 얻기 어려우 며, 중심부 바늘 생검을 하면 조직학적 진단이 가능하다. 자기 공명영상은 병변의 범위를 확인하는 데 우수한 영상검사로 
Table 1. Recurrence rate of fibromatosis after surgery, RT, and both therapies, respectively

\begin{tabular}{|c|c|c|c|c|c|c|}
\hline \multirow{2}{*}{ Author } & \multirow{2}{*}{ Total case } & \multicolumn{3}{|c|}{ Recurrence rate (\%) } & \multirow{2}{*}{$\begin{array}{l}\text { Median } \\
\text { follow-up }\end{array}$} & \multirow{2}{*}{$\begin{array}{c}\text { Mean } \\
\text { follow-up }\end{array}$} \\
\hline & & Surgery alone & Surgery and RT & RT alone & & \\
\hline Nuyttens, et al. ${ }^{12)}$ & 780 & $147 / 381(38.6)$ & $74 / 297(24.9)$ & $22 / 102(21.6)$ & 6.0 years & 7.3 years \\
\hline Ballo, et al. ${ }^{13)}$ & 189 & $46 / 122(38)$ & $11 / 46(25)$ & $5 / 21(24)$ & 9.4 years & \\
\hline Shin, et al. ${ }^{14)}$ & 20 & $3 / 9(33.3)$ & $2 / 11(18.2)$ & & & 2.7 years \\
\hline Spear, et al. ${ }^{15)}$ & 107 & $16 / 51(31)$ & $3 / 41(7)$ & $4 / 15(28)$ & & 5 years \\
\hline
\end{tabular}

$\mathrm{RT}$ : radiotherapy

병변이 $\mathrm{T} 1$ 강조영상에서는 균일한 저신호 강도를, $\mathrm{T} 2$ 강조영 상에서는 불균질한 고신호 강도를 보이고, 전반적으로 조영 증 강되는 소견을 보이며 본 증례에서도 이러한 소견을 나타내 었다. ${ }^{9}$

유섬유형 섬유종증의 치료는 종괴의 경계를 포함하는 완 전 절제를 시행하는 것이 추천되고 있다. ${ }^{1-3,4-7)}$ 하지만 두경부 는 해부학적 구조가 복잡하고 중요 구조물이 인접해 있어 병 변의 충분한 노출이 제한되어 완전 절제가 어려운 경우가 많 다. ${ }^{1,2,4,10)}$ 중요한 장기들에 침범이 있는 경우에는 기능적 절제 를 시행함으로써 팔 얼기 신경이나 횡경막 신경, 척수부신경, 경동맥 등의 중요 구조물들을 보존하면서 최대한 종괴를 제 거하는 술식을 시행하여야 한다. ${ }^{1)}$ 수술을 계획할 때 컴퓨터단 층촬영이나 자기공명영상 등으로 병변의 범위를 파악하여 외 과적 절제 방법의 계획을 세우는 데 도움을 받아야 하며, 수 술 전에 환자에게 발생 가능한 합병증을 미리 예측하고 고지 하여야 한다. ${ }^{11}$

유섬유형 섬유종증은 완전 절제가 불가능한 경우 술 후 방 사선 치료를 시행함으로써 크기 감소를 유도해 볼 수 있으나, 그 효용성에 대해서는 아직 논란이 되고 있다.,2) 하지만 저자 들이 참고한 많은 문헌상 종괴를 불완전 절제하여 방사선 치 료를 추가한 경우에 재발률이 낮은 것을 알 수 있었고(Table 1), 본 증례 환자의 경우 중요 신경과 인접하고, 경추의 가로 돌기에 유착되어 있어 가로돌기까지 제거하였으나 충분한 절 제연을 확보하기 어려워 환자에게 방사선 치료를 권유하여 시행하였다. ${ }^{12-15)}$

결론적으로 유섬유형 섬유종증이 두경부 영역에서 발생한 경우 해부학적인 구조로 인하여 수술 시에 충분한 절제연을 확보하지 못할 수 있으며, 이러한 기능적 절제술을 시행한 경 우 재발을 줄이기 위하여 여러 문헌을 참고하여 술 후 추가 적인 방사선 치료가 도움이 될 수 있다고 저자들은 판단하였 다. 본 증례에서 저자들은 유섬유형 섬유종증을 중심부 바 늘 생검하여 진단하고 종양 절제 후 방사선 치료를 추가로
시행한 귀중한 경험을 하였기에 문헌고찰과 함께 보고하는 바이다.

\section{REFERENCES}

1) Hoos A, Lewis JJ, Urist MJ, Shaha AR, Hawkins WG, Shah JP, et al. Desmoid tumors of the head and neck--a clinical study of a rare entity. Head Neck 2000;22(8):814-21.

2) Wang CP, Chang YL, Ko JY, Cheng CH, Yeh CF, Lou PJ. Desmoid tumor of the head and neck. Head Neck 2006;28(11):1008-13.

3) Fasching MC, Saleh J, Woods JE. Desmoid tumors of the head and neck. Am J Surg 1988;156(4):327-31.

4) Siegel NS, Bradford CR. Fibromatosis of the head and neck: a challenging lesion. Otolaryngol Head Neck Surg 2000;123(3):269-75.

5) Conley J, Healey WV, Stout AP. Fibromatosis of the head and neck. Am J Surg 1966;112(4):609-14.

6) Gnepp DR, Henley J, Weiss S, Heffner D. Desmoid fibromatosis of the sinonasal tract and nasopharynx. A clinicopathologic study of 25 cases. Cancer 1996;78(12):2572-9.

7) Abdelkader M, Riad M, Williams A. Aggressive fibromatosis of the head and neck (desmoid tumours). J Laryngol Otol 2001;115(10): $772-6$.

8) Enzinger FM, Weiss SW. Soft tissue tumors. 3rd ed. St. Louis: Mosby; 1995. p.251-6.

9) Castellazzi G, Vanel D, Le Cesne A, Le Pechoux C, Caillet H, Perona F, et al. Can the MRI signal of aggressive fibromatosis be used to predict its behavior? Eur J Radiol 2009;69(2):222-9.

10) Masson JK, Soule EH. Desmoid tumors of the head and neck. Am J Surg 1966;112(4):615-22.

11) Yi JS, Kang BC, Ryu CH, Park JT, Roh JL, Choi SH, et al. Clinical outcome of fibromatosis of the head and neck region. Korean $\mathrm{J}$ Otorhinolaryngol-Head Neck Surg 2013;56(3):144-8.

12) Nuyttens JJ, Rust PF, Thomas CR Jr, Turrisi AT 3rd. Surgery versus radiation therapy for patients with aggressive fibromatosis or desmoid tumors: a comparative review of 22 articles. Cancer 2000;88(7):151723.

13) Ballo MT, Zagars GK, Pollack A, Pisters PW, Pollack RA. Desmoid tumor: prognostic factors and outcome after surgery, radiation therapy, or combined surgery and radiation therapy. J Clin Oncol 1999;17(1):158-67.

14) Shin KH, Shin SJ, Lee DH, Kang ES, Suh CO. The role of radiotherapy in the treatment of aggressive fibromatosis. Yonsei Med J 1999;40(5): 439-43.

15) Spear MA, Jennings LC, Mankin HJ, Spiro IJ, Springfield DS, Gebhardt MC, et al. Individualizing management of aggressive fibromatoses. Int J Radiat Oncol Biol Phys 1998;40(3):637-45. 